\title{
Identifying the Primary Site Using Gene Expression Profiling in Patients with Carcinoma of an Unknown Primary (CUP): A Feasibility Study from the GEFCAPI
}

\author{
Marine Gross-Goupil ${ }^{\mathrm{a}} \quad$ Christophe Massard ${ }^{\mathrm{a}} \quad$ Thierry Lesimple $^{\mathrm{b}} \quad$ Yacine Merrouche $^{\mathrm{c}}$ \\ Emmanule Blot ${ }^{\mathrm{d}}$ Yohan Loriot ${ }^{\mathrm{a}}$ Marie C. Mathieu ${ }^{\mathrm{c}}$ Karim Fizazi $^{\mathrm{a}}$ \\ aDepartment of Medicine, Institut Gustave Roussy, Villejuif, 'bepartment of Medicine, Centre Eugène Marquis, Rennes, \\ 'Department of Medicine, Institut de Cancérologie de la Loire, Saint-Etienne, 'Department of Medicine, Centre Henri Becquerel, Rouen, \\ ${ }^{3}$ Department of Pathology, Institut Gustave Roussy, Villejuif, France
}

\section{Keywords \\ Cancer of unknown primary, diagnosis - Gene expres- sion \\ Schlüsselwörter \\ Karzinom bei unbekanntem Primärtumor, Diagnose . Genexpression}

Carcinomas of an unknown primary site (CUP) rank among the 10 most frequent cancers worldwide and its prognosis is notoriously poor with median survival rates attaining 8 months [1]. CUP are heterogeneous tumors whose origin is unidentifiable at the time of the diagnosis but they share the unique clinical feature of metastatic disease. New molecular diagnosis tools with DNA array could be a promising technology in the search of lost CUP origins [2, 3]. Using this large database, Horlings developed a diagnostic gene expression based classifier (CupPrint $^{\circledR}$, Agendia BV, Amsterdam, The Netherlands) in order to diagnose the histogenic background of CUP in daily practice [4]. The CupPrint assay was, at the time of the study, commercialized by Agendia.

We report here the results of a prospective study of feasibility conducted by the GEFCAPI (Groupe d'Etude Français des Carcinomes de site Primitif Inconnu), in collaboration with the Agendia team [4]. The aim of this study was to evaluate the feasibility of integrating an oligonucleotide microarray, that contains 495 genes selected as highly differentially expressed between 49 tumor types (CupPrint). The sample's gene expression profile is compared to a previously built tumor gene expression data set encompassing 49 primary tumor types to identify the tissue of origin in patients with CUP. Formalin-fixed, paraffin-embedded (FFPE) specimens from diagnostic biopsies of 22 patients with CUP were prospectively collected. The assay was successfully performed on specimens from 18 of the 22 patients $(82 \%)$. In the remaining 4 cases the test could not be performed because of low RNA preservation in the specimens. Results concerning the 18 patients are reported in the table 1 , with 5 suggested tumor types according to the gene expression profile and final suggested diagnosis, integrating analysis of medical history, immunohistochemistry, and type of biopsy. The median age of the patients was 54 years (range: $29-70$ years). The median delay from tissue shipping to receipt of CupPrint result was 11 days (range: 1-26 days). The most common tissues of origin identified were lung cancer (22\%) and colorectal cancer (17\%). Of note, primary cancers which would not be adequately treated by an empiric chemotherapy regimen currently recommended in CUP (such as cisplatin-gemcitabine or carboplatin-paclitaxel) was identified in about half of the patients: kidney cancer (1), hepatocarcinoma (1), colorectal cancer (3), head and neck cancer (2), cholangiocarcinoma (1) (table 1).

At least two clinical cases suggested the potential implication of adjusting treatment according to the suggested primary. The first patient, a 50-year-old woman (patient 1, table 1), presented with a swollen left inguinal lymph node. The biopsy specimen revealed an undifferentiated carcinoma, ck7-, ck20-, RE-, PS100-, EMA- (07/2008). The CupPrint suggested the diagnosis of breast cancer, melanoma, or oral carcinoma. She underwent an inguinal dissection that showed a metastasis from melanoma (PS100 and vimentin positive). The dermatological examination revealed a lesion of the skin on the left knee. Surgical excision and histology confirmed the diagnosis of a superficial melanoma, SSM level 2, $0.44 \mathrm{~mm}$ deep. The patient is still in remission.

The second case, a 63-year-old woman, presented with swollen left supra-clavicular, mediastinal and axillary lymph nodes (patient 2, table 1). The axillary lymph node dissection revealed an epidermoid carcinoma (ck7+, 20-). The CupPrint

\section{KARGER}

Fax +497614520714

Information@Karger.de

www.karger.com (c) 2012 S. Karger GmbH, Freiburg

0378-584X/12/0351-0054\$38.00/0

Accessible online at:

www.karger.com/onk
Dr. Marine Gross-Goupil

Gustave Roussy Institute

39 Rue Camille Desmoulins

94805 Villejuif Cedex, France

Tel. +33 14211-4898, Fax -5211

marine.grossgoupil@igr.fr 
Table 1. Suggested primary diagnosis (5 preliminary diagnoses and final considered diagnosis) with CupPrint for the 18 patients (pt)

\begin{tabular}{|c|c|c|c|c|c|c|}
\hline $\mathrm{Pt}$ & 1st tumor type & $2^{\text {nd }}$ tumor type & 3rd tumor type & 4th tumor type & 5th tumor type & $\begin{array}{l}\text { final suggested } \\
\text { diagnosis }\end{array}$ \\
\hline 1 & melanoma & breast cancer & breast cancer & small cell lung cancer & & breast cancer \\
\hline 2 & $\begin{array}{l}\text { hypopharyngeal } \\
\text { cancer }\end{array}$ & $\begin{array}{l}\text { hypopharyngeal } \\
\text { cancer }\end{array}$ & $\begin{array}{l}\text { hypopharyngeal } \\
\text { cancer }\end{array}$ & $\begin{array}{l}\text { non small cell lung } \\
\text { cancer }\end{array}$ & urothelial carcinoma & hypopharyngeal cancer \\
\hline 3 & urothelial carcinoma & urothelial carcinoma & $\begin{array}{l}\text { non-small cell lung } \\
\text { cancer }\end{array}$ & $\begin{array}{l}\text { non-small cell lung } \\
\text { cancer }\end{array}$ & hepatocarcinoma & urothelial carcinoma \\
\hline 4 & breast cancer & $\begin{array}{l}\text { hypopharyngeal } \\
\text { cancer }\end{array}$ & urothelial carcinoma & urothelial carcinoma & $\begin{array}{l}\text { non-small cell lung } \\
\text { cancer }\end{array}$ & urothelial carcinoma \\
\hline 5 & cholangiocarcinoma & cholangiocarcinoma & cholangiocarcinoma & hepatocarcinoma & hepatocarcinoma & pancreatic carcinoma \\
\hline 6 & $\begin{array}{l}\text { non-small cell lung } \\
\text { cancer }\end{array}$ & pancreatic carcinoma & cholangiocarcinoma & $\begin{array}{l}\text { adenocarcinoma of } \\
\text { the colon/rectum }\end{array}$ & urothelial carcinoma & $\begin{array}{l}\text { non-small cell lung } \\
\text { cancer }\end{array}$ \\
\hline 7 & hepatocarcinoma & hepatocarcinoma & hepatocarcinoma & hepatocarcinoma & hepatocarcinoma & $\begin{array}{l}\text { adenocarcinoma of } \\
\text { the colon/rectum }\end{array}$ \\
\hline 8 & cholangiocarcinoma & pancreatic carcinoma & $\begin{array}{l}\text { non-small cell lung } \\
\text { cancer }\end{array}$ & pancreatic carcinoma & cholangiocarcinoma & cholangiocarcinoma \\
\hline 9 & $\begin{array}{l}\text { adenocarcinoma of } \\
\text { the colon/rectum }\end{array}$ & $\begin{array}{l}\text { adenocarcinoma of } \\
\text { the colon/rectum }\end{array}$ & $\begin{array}{l}\text { adenocarcinoma of } \\
\text { the colon/rectum }\end{array}$ & breast cancer & small bowel carcinoma & $\begin{array}{l}\text { adenocarcinoma of } \\
\text { the colon/rectum }\end{array}$ \\
\hline 10 & $\begin{array}{l}\text { non-small cell lung } \\
\text { cancer }\end{array}$ & $\begin{array}{l}\text { non-small cell lung } \\
\text { cancer }\end{array}$ & $\begin{array}{l}\text { non-small cell lung } \\
\text { cancer }\end{array}$ & $\begin{array}{l}\text { non-small cell lung } \\
\text { cancer }\end{array}$ & meningioma & $\begin{array}{l}\text { non-small cell lung } \\
\text { cancer }\end{array}$ \\
\hline 11 & small cell lung cancer & small cell lung cancer & small cell lung cancer & $\begin{array}{l}\text { non-small cell lung } \\
\text { cancer }\end{array}$ & $\begin{array}{l}\text { squamous cell } \\
\text { carcinoma of the skin }\end{array}$ & small cell lung cancer \\
\hline 12 & $\begin{array}{l}\text { hypopharyngeal } \\
\text { cancer }\end{array}$ & $\begin{array}{l}\text { hypopharyngeal } \\
\text { cancer }\end{array}$ & oral cavity carcinoma & $\begin{array}{l}\text { cervix squamous cell } \\
\text { carcinoma }\end{array}$ & $\begin{array}{l}\text { cervix squamous cell } \\
\text { carcinoma }\end{array}$ & hypopharyngeal cancer \\
\hline 13 & renal cell cancer & renal cell cancer & renal cell cancer & urothelial carcinoma & renal cell cancer & renal cell cancer \\
\hline 14 & mesothelioma & mesothelioma & mesothelioma & mesothelioma & mesothelioma & mesothelioma \\
\hline 15 & ovarian carcinoma & ovarian carcinoma & $\begin{array}{l}\text { endometrial } \\
\text { carcinoma }\end{array}$ & ovarian carcinoma & ovarian carcinoma & ovarian carcinoma \\
\hline 16 & hepatocarcinoma & hepatocarcinoma & $\begin{array}{l}\text { hypopharyngeal } \\
\text { cancer }\end{array}$ & $\begin{array}{l}\text { non-small cell lung } \\
\text { cancer }\end{array}$ & $\begin{array}{l}\text { non-small cell lung } \\
\text { cancer }\end{array}$ & hepatocarcinoma \\
\hline 17 & $\begin{array}{l}\text { non-small cell lung } \\
\text { cancer }\end{array}$ & $\begin{array}{l}\text { non-small cell lung } \\
\text { cancer }\end{array}$ & $\begin{array}{l}\text { hypopharyngeal } \\
\text { cancer }\end{array}$ & urothelial carcinoma & $\begin{array}{l}\text { adenocarcinoma of } \\
\text { the colon/rectum }\end{array}$ & $\begin{array}{l}\text { non-small cell lung } \\
\text { cancer }\end{array}$ \\
\hline 18 & $\begin{array}{l}\text { adenocarcinoma of } \\
\text { the colon/rectum }\end{array}$ & $\begin{array}{l}\text { adenocarcinoma of } \\
\text { the colon/rectum }\end{array}$ & $\begin{array}{l}\text { adenocarcinoma of } \\
\text { the colon/rectum }\end{array}$ & $\begin{array}{l}\text { adenocarcinoma of } \\
\text { the colon/rectum }\end{array}$ & $\begin{array}{l}\text { non-small cell lung } \\
\text { carcinoma }\end{array}$ & $\begin{array}{l}\text { adenocarcinoma of } \\
\text { the colon/rectum }\end{array}$ \\
\hline
\end{tabular}

suggested that the diagnosis was a hypopharyngeal carcinoma. Treatment with 4 cycles of cisplatin, 5-fluorouracil, and cetuximab resulted in a partial response (12/2008). Then she received concomitant radio-chemotherapy which led to tumor regression. The patient is still in complete remission (07/2009).

In the present study, we showed that CupPrint diagnosis is feasible in daily practice without delaying treatment, and may change the chemotherapy regimen and clinical management in more than $50 \%$ of patients. This new diagnosis tool could improve the prognosis in CUP patients, as suggested by Bridgewater et al. [5]. The feasibility of integrating a gene expression analysis allowed us to elaborate the GEFCAPI-04 trial. This randomized phase III trial is planned to compare therapy based on gene expression-suspected primary cancer versus empiric chemotherapy. The main objective will be to demonstrate a benefit in progression free survival in patients receiving 'individualized' treatment, including chemotherapy and targeted therapies.

\section{Disclosure Statement}

None of the authors declares a conflict of interest.

\section{References}

1 ESMO minimal recommendations for diagnosis, treatment and follow-up of cancers of unknown primary site (CUP). Ann Oncol 2001;12:1057-1058.

2 Varadhachary GR, Talantov D, Raber MN, et al.: Molecular profiling of carcinoma of unknown primary and correlation with clinical evaluation. J Clin Oncol 2008;26:4442-4448.
3 Erlander MG, Moore MW, Cotter P, et al.: Molecular classification of carcinoma of unknown primary by gene expression profiling from formalin-fixed paraffin-embedded tissues. J Clin Oncol 2002;22(14S):9545.
4 Horlings HM, van Laar RK, Kerst JM, et al.: Gene expression profiling to identify the histogenetic origin of metastatic adenocarcinomas of unknown primary. J Clin Oncol 2008;26:4435-4441.

5 Bridgewater J, van Laar R, Floore A, Van't Veer L: Gene expression profiling may improve diagnosis in patients with carcinoma of unknown primary. Br J Cancer 2008;98:1425-1430. 